\author{
Annemarie Sorescu-Marinković \\ (Serbian Academy of Sciences and Arts, Belgrade, Serbia) \\ Mircea Măran \\ (Pre-school Teacher Training College "Mihailo Palov" in Vršac, Serbia)
}

\title{
The Meglen Vlachs (Megleno-Romanians) of Serbia: a Community on the Verge of Extinction*
}

\author{
Megleno-Wołosi (Megleno-Rumuni) w Serbii: społeczność \\ na skraju wyginięcia
}

\section{STRESZCZENIE}

Celem artykułu jest przedstawienie społeczności megleno-wołoskiej w Serbii, zamieszkującej kilka wsi położonych nieopodal granicy z Rumunią. Z powodu niewielkiej liczby mieszkańców społeczność ta nie była do tej pory znana środowisku naukowemu czy większości mieszkańców Serbii. Megleno-Wołosi przybyli tutaj w latach pięćdziesiątych XX stulecia z miejscowości Huma (obecnie na obszarze Byłej Jugosławiańskiej Republiki Macedonii) i pozostawali „niewidzialni” w oficjalnych statystykach, będąc „ukrytymi" wśród macedońskich kolonistów, a ich zadanie polegało na ponownym zasiedleniu, wspólnie z innymi Jugosłowianami, dawnych wsi niemieckich. Jednakże już wkrótce wielu spośród nich powróciło do domów, osiedliło się w innych miejscowościach na terenie Macedonii lub wyemigrowało do państw zachodnioeuropejskich. Dzisiaj dialektem megleno-wołoskim czynnie posługuje się kilkoro ludzi (terminal speaker, wedle terminologii lingwistycznej), urodzonych w okresie międzywojennym. W artykule postarano się udzielić odpowiedzi na pytanie, czy dialekt ten pozostaje mocno zagrożony, czy też już stał się językiem zdezaktualizowanym. Pokazano też, że lingwistyczna i kulturowa przyszłość Megleno-Wołochów w Serbii nieuchronnie zmierza ku akulturacji i asymilacji.

Słowa kluczowe: Megleno-Wołosi, niewidzialna mniejszość, Jugosławia, język zagrożony

* This essay originates from a project of the Institute for Balkan Studies in Belgrade, Language, Folklore, Migrations in the Balkans (no. 178010), funded by the Ministry of Education and Science of the Republic of Serbia. 
WHO ARE THE MEGLEN VLACHS?

The Meglen Vlachs are one of the branches of the Balkan Romance population, who are closely related linguistically to the Aromanians, Daco-Romanians and Istro-Romanians, and originally inhabited the Meglen region in Central Macedonia: north-west of Thessaloniki, between the Vardar River and the mountains of Kožuf and Pajak. Megleno-Romanian is only a scientific construct used to refer to this population, which proves to be quite inexact, as they are the only Balkan Romance population which has lost the ethnonym Romanians and call themselves Vlachs, as most of their neighbours also refer to them.

Romanian linguists consider Megleno-Romanian, apart from Aromanian and Istro-Romanian, to be a historic dialect of the Romanian language. However, others think all three dialects spoken south of the Danube River are languages in their own right. Daco-Romanian, which is spoken north of the Danube, is the only one which acquired the status of literary and official language in Romania and the Republic of Moldova. MeglenoRomanian has more in common with Romanian than Aromanian, the assumption therefore being that the Meglen Vlachs broke away from the Romanian population at a later date than the Aromanians.

The ancestors of the Meglen Vlachs are said to have belonged to Bulgarian-Vlach groups which after the battle of Kosovo in 1389 fled to the Karačova heights in Central Macedonia ${ }^{1}$. The area offered favourable climate and good land, which made the Meglen Vlachs give up their nomadic lifestyle and settle down. This view, however, is far from unanimous. Following Konstantin Jireček², many authors believe that the Meglen Vlachs mixed with the Pechenegs, who, after losing a battle against the Byzantine Emperor Alexios I Komnenos in 1091, were settled as military colonists in the Meglen area. This theory, in which the Vlachs mixed with the Pechenegs, has an alternative version where the Vlachs mixed with the Cumans ${ }^{3}$.

During the ascension of the Ottoman Empire and its expansion to the north and west, Macedonia was transformed from a frontier area into a central region of the European part of the Empire. The anarchy which

${ }^{1}$ G. Weigand, Vlacho-Meglen. Eine ethnographisch-philologische Untersuchung, Leipzig 1892, pp. 53-55.

2 K. Jireček, Über die Wlachen von Moglena, “Archiv für Slavische Philologie” 1893, 15, pp. 95-97.

${ }^{3}$ For details see T. Kahl, The Islamisation of the Meglen Vlachs (Megleno-Romanians): The Village of Nânti (Nótia) and the "Nântinets" in Present-Day Turkey, "Nationalities Papers" 2006, 34, 1, pp. 71-90. 
dominated the Ottoman society starting in the $17^{\text {th }}$ century and the wars against Christian powers from which the Ottoman Empire depleted its last economic resources contributed to the worsening position of the Christian population in Macedonia. These events triggered waves of emigration to other parts of the Balkan Peninsula and to the West, but also to a rise in the interest of new Balkan national states in chasing away the Ottomans and recapturing these territories. The Oriental Question receives new interest in the second half of the $19^{\text {th }}$ century and the beginning of the $20^{\text {th }}$ when the young Balkan states - such as Serbia, Romania, Greece, Bulgaria, and Montenegro - begin to be interested in the Balkan territories which had yet to be freed, including the territory of Macedonia.

During the Ottoman Empire, the part of the Meglen region, which was populated by Meglen Vlachs, was a compact enclave; however, today the Meglen Vlachs are dispersed over several states. The crucial moment in their recent history occurred in the aftermath of World War I when the border between Greece and the Kingdom of Serbs, Croats and Slovenes was definitely fixed. Most Meglen Vlach villages (Liumnița, Cupa, Oşani, Birislăv, Lundzini and Țărnareca) became part of Greece, Uma (Huma) and the few Meglen Vlach families in Gevgelija and the surrounding villages became part of the new territory of Yugoslavia. Henceforth, a linguistic gap between the dialects spoken on the two sides developed, resulting mainly in the usage of different words. The Megleno-Romanian dialect, rather homogenous before, was now influenced by both the Greek and the Macedonian language ${ }^{4}$.

Most Meglen Vlachs are Christian Orthodox. Under Ottoman rule they resisted Islamization with the notable exception of the village of Nânti, whose population converted to Islam in the $18^{\text {th }}$ century. One of the consequences of the Greek-Turkish war of 1919-1922 was forced population exchange. The Meglen Vlachs of Nânti, the largest Meglen Vlach village of the time, who had converted to Islam a few centuries earlier, were forced to leave their home for Turkey. At the same time (1925-1933), about 5,000 Aromanian and Meglen Vlach families move to Dobrudza ${ }^{5}$. Out of these, 450 families of Meglen Vlach origin, especially from Liumnița, Cupa, Oşani, Birislav, Livezi and Lundzini, moved to Durostor in Dobrudza. After the Treaty of Craiova (1940), through which Romania gave Cadrilater away, one more population exchange took place between Romania and Bulgaria: the Meglen Vlachs are now compactly colonised in the village of

${ }^{4}$ For a thorough linguistic description of Megleno-Romanian, see P. Atanasov, Meglenoromâna astăzi, Bucureşti 2002.

${ }^{5}$ N. Saramandu, Die Aromunen in der Dobrudsha und ihre Mundart, "Dacoromania" 1975, 3, pp. 185-196. 
Cerna. Between 1947 and 1948, 40 Meglen Vlach families are deported to Ialomița, Brăila and Banat, and only a few return.

Today, the Meglen Vlachs live in Greece and the Republic of Macedonia (their "native" homelands), Turkey and Romania (their "adopted" homelands), but also, to a much smaller extent in Serbia (which has become home to a small group of Meglen Vlachs - the focus of our paper) and different countries in Western Europe where they have recently emigrated. The top estimate of the total population of Meglen Vlachs in all these areas today is around 14,000 people.

\section{MACEDONIANS' COLONIZATION IN BANAT}

At the end of WWII when the Yugoslav Communist Party came to power in Yugoslavia, large population movements were recorded all over the state. These dislocations were meant mainly in order to move families from the regions deserted by war (passive zones), with an underdeveloped economy, to the more developed regions of Yugoslavia, most of the times to Vojvodina. Estimates have it that during this period approximately 60,000 families have been colonized in Vojvodina. The communist authorities have retorted to this measure due to the fact that many villages were emptied after the German population had been forcefully evacuated, but also as a result of a descending demographic movement, already present in the previous decades, caused by the negative birth rate and emigration to America.

Colonisations were supposed to strengthen the South-Slav element present in Banat and Bačka, where mainly non-Slavic population was living, of Hungarian and Romanian origin. Among the colonisers there were poor families from Dalmatia, Lika, Kordun, Bosanska Krajina, Herzegovina, Montenegro and Macedonia, but also from other regions. This population was supposed to be loyal to the new regime so it could consolidate the new reign in the agricultural region north of Danube, where parts of population were hostile to the communist ideology, especially to the measures employed against the middle and rich peasantry (the agrarian reform, nationalization, etc.). The communists were presenting colonisation as an "integral part of solving the peasants' problem", as an "important socio-political means of the revolutionary power which could solve the socio-economic situation of the population in the passive and war deserted regions, as well as the issue of labour shortage for working the land in Vojvodina, deserted after the German ethnic group left, together with the Nazi troupes"6.

${ }^{6}$ Istorija Saveza komunista Jugoslavije, Beograd 1985, p. 341. 
Among the population colonized in Banat (which geographically and administratively belonged to the Autonomous Province of Vojvodina) there were also inhabitants from Macedonia - Macedonian Slavs who, in the previous years, had not yet formed a solid national identity, a population which has been treated by the authorities of the Yugoslav Kingdom in the interwar period as a Serbian one and during the Bulgarian occupation of Macedonia, in WWII, as a Bulgarian one. In line with the "brotherhood and unity" slogan, the Yugoslav post-war communist regime encouraged the formation of the Macedonian nation, with the aim of neutralizing the Bulgarian influence upon Yugoslav Macedonia and, at the same time, of weakening, as much as possible, the Serbian element in the new Yugoslav federation, which was the most numerous and would unbalance the ethnic map of socialist Yugoslavia and the interests of Tito's regime. This is why the formation of the Popular Republic of Macedonia represented one of Tito's manoeuvres supposed to help him unlimitedly control a territory which was highly diverse, ethnically speaking, and thus to assume power over the entire territory of the country.

The colonization of Macedonians in Banat started in January 1946. The biggest number of families settled in Kačarevo, Jabuka, Glogoni, Plandište, Hajdučica, Stari Lec, Dužine and Gudurica, with smaller numbers also in other localities. Only in the first three mentioned villages, which are located in the neighbourhood of the town of Pančevo, 209 inhabitants from Macedonia settled ${ }^{7}$. The first train with Macedonian colonists arrived in the Banat village of Jabuka on 6 January 1946. In April and May, the families settled here already brought their cattle and sheep ${ }^{8}$. At the beginning of May, a bigger group of colonists from Macedonia settled in Jabuka. Until the end of summer of 1946, the colonisation has been almost finalized. Between 1947 and 1956, a few poor families from the mountains of Macedonia also settled here. In this village 561 families with 3,464 members were colonised; among them, there were 13 families of Roma and four of Aromanians. Most of them were coming from the administrative regions of Kriva Palanka, Porečje and Struga. Each family received, depending on the number of family members, land, tools for working the land, food, etc. During the next years some more families came from Macedonia on their own initiative (the so-called self-colonizers), adding to the Macedonians already living here.

${ }^{7}$ J. F. Trifunoski, O posleratnom naseljavanju stanovništva iz NR Makedonije u tri banatska naselja - Jabuka, Kačarevo i Glogonj, Novi Sad 1958, pp. 12-13.

${ }^{8}$ S. Mladenovski, Банатско село Јабука, Скопје 1988, p. 84. 
The main reason behind the colonization of Macedonian population in Banat was the fact that the villages of Macedonia were over-populated. The families which came from Albania, on the other hand, were running away from the terror of the authorities in this state. The newcomers faced many obstacles in the villages they settled in, thereupon from 1947 onwards there have been numerous cases of discontent with the new environment. The reason for dissatisfaction was the impossibility of some families to adapt to the Banat climate, with strong winds, dust and big variations in temperature. The well water, type of houses, furniture and food were also causing problems ${ }^{9}$. As a consequence, the number of people falling ill has sky rocketed, sometimes with fatal consequences. Another issue was that the majority of the colonists came from mountain regions and did not know how to work the land, especially when it came to farming. Many families, failing to adjust, returned to Macedonia. There were 122 families which came back only from Jabuka, mainly in 1947-1948. Other families from Macedonia took their place later. Those who managed to adjust have stayed there for good.

Virgil Coman's observation is illustrative in this respect. The Romanian historian thinks that, overall, the Meglen Vlachs in Yugoslavia evolved after World War II within the communist system imposed by Tito, which was different from Stalin's, dominating the neighbouring communist states. At the same time, forcefully or willingly giving up on the old occupations and migration to urban areas did nothing but further "diluted" ethnically the mass populations of Meglen Vlachs in their homeland ${ }^{10}$.

Among the Macedonians colonized in Banat there was also a small group of "Vlachs" - speaking Aromanian and Megleno-Romanian - but who went almost unnoticed in the bigger mass of Macedonian Slavs. In almost all the localities where population from Macedonia was colonized, there were also Aromanians, in smaller numbers referred to as Cincari or Vlasi by the Serbian population. They were very quickly assimilated by the majority of the Macedonian or Serbian population and did not get the chance of having schools, cultural societies or other institutions where they could use their mother tongue. The Meglen Vlachs, on the other hand, even less numerous than Aromanians, almost all coming from Huma near Djevdjelija, found themselves in an even worse situation: they transformed in no time into an invisible minority, which went unnoticed and unknown.

${ }^{9}$ J. F. Trifunoski, op. cit., pp. 19-20.

${ }^{10} \mathrm{~V}$. Coman, Scurtă privire asupra meglenoromânilor până la sfârşitul secolului al XXlea, in: Aromâni, meglenoromâni, istroromâni - Aspecte identitare şi culturale, ed. A. BerciuDrăghicescu, Bucureşti 2012, pp. 109-238. 
They were an invisible minority as the authorities did not recognize ethnic groups apart from the six acknowledged ones, which were part of the "brotherhood and unity" of communist Yugoslavia (Serbs, Croats, Slovenes, Macedonians, Montenegrins and Yugoslav Muslims). The Aromanians and Meglen Vlachs were thus victims of the Yugoslav communist national policy, which sought to create a single Macedonian nation. Due to the small number of Macedonians, who were supposed to be one of the six peoples (nations) constituting the Yugoslav federation, the new Yugoslav regime needed citizens to "fill the gaps" and found among them the Romanophone population in Macedonia, speaking two historic Romanian dialects: Aromanian and Megleno-Romanian.

Most of the Meglen Vlach families were colonized in Gudurica near $\operatorname{Vršac}^{11}$, an outstanding village due to the very high number of ethnicities living here together. Up to WWII, Gudurica had mostly German population and was a thriving village, best known for wine making. The Germans left the village in 1945 and colonists from different parts of Yugoslavia came here, including Macedonia. The families of Meglen Vlachs were colonized on one of the streets of Gudurica, but the majority could not adjust to the new living conditions and returned to Macedonia. The ones who remained (among them the Proševski and Djoševski families) went almost unnoticed in the mass of other Macedonians.

As far as the village of Jabuka near Pančevo is concerned, among the Macedonian colonists settled there in 1946 there were also families from Djevdjelija, from the villages of Huma and Mojina: the Lešovski family (Nikola, Dimitrije and Jovan) and the Mitreski family ${ }^{12}$. We can suppose these families were of Meglen Vlach origin and the information regarding the four Aromanian families colonized in Jabuka in fact makes reference to them ${ }^{13}$. Obviously, neither the authorities nor the population could make the difference between the "Vlachs" speaking Aromanian and those speaking Megleno-Romanian. Lost in a much larger group of Macedonian settlers, they were officially non-existent as a separate ethnic group. As their ethnic identity was rather weak, the Meglen Vlachs and Aromanians who settled in Banat were assimilated quickly, mainly through mixed marriages. With a few exceptions, most children from ethnically homogeneous marriages did not learn their ancestors' language. Thus, this dialect is today almost erased from the linguistic map of Banat and of Serbia, as we shall see.

${ }^{11}$ A. Sorescu-Marinković, M. Măran, Megleno-Romanians in Gudurica: Language and Identity, "Memoria Ethnologica" 2014, 52-53, pp. 82-101.

${ }^{12}$ S. Mladenovski, op. cit., p. 247.

${ }^{13}$ Ibidem, p. 90. 
Apart from the historical evidence of the colonization of Meglen Vlachs in Banat, we also have evidence from other sources. The Macedonian linguist of Meglen Vlach descent, Petar Atanasov, in his monograph MeglenoRomanian today mentions that "from the desire to change their way of life, at the end of World War II, several Meglen Vlachs families from Huma moved to Gevgelija, and others to Vojvodina, settling in the villages of Jabuka, Kačarevo and Gudurica, where the Germans left from" ${ }^{14}$. Whether or not this was indeed their desire, or whether they were forced to do so, remains unclear. The exact number of Meglen Vlachs established in Vojvodina is also unknown, as well as the number of returnees to the Republic of Macedonia, where they are now settled in urban areas.

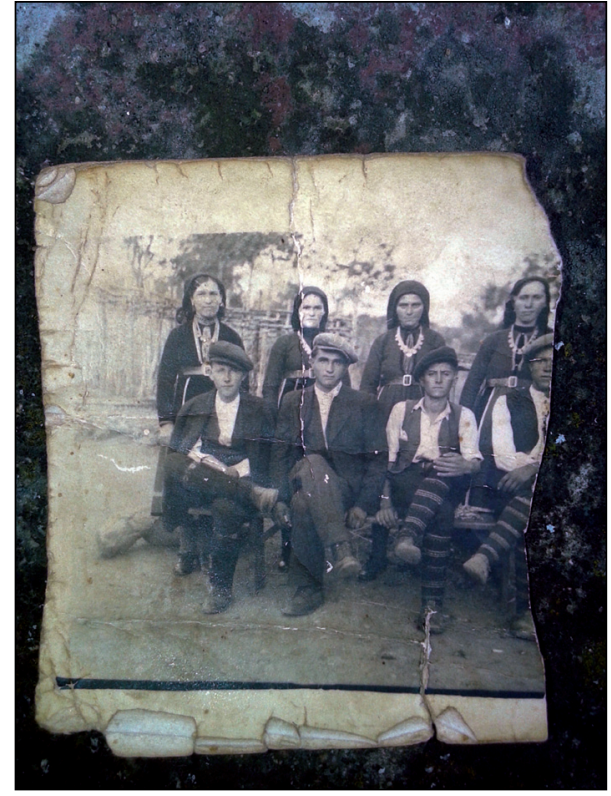

Figure 1. Young Meglen Vlach couples, Huma, 1930s (private collection of Kristina and Blagoje Djoševski)

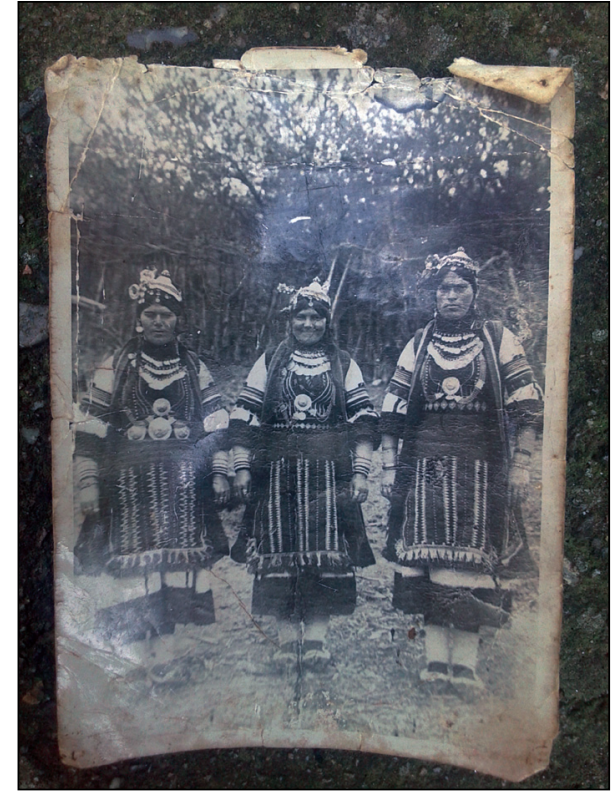

Figure 2. Meglen Vlach women in traditional costumes, Huma, 1900s (private collection of Kristina and Blagoje Djoševski)

Today, there are probably a few tens of Meglen Vlachs in the Serbian Banat and probably the same number in the Romanian part of Banat as well. The Serbian publicist Stvetlana Nikolin drew attention to the exis-

${ }^{14}$ P. Atanasov, op. cit., p. 11. 
tence of the tiny Meglen Vlach community in Gudurica in 2012 in a published report called Megleno-Romanians of South Banat. She included excerpts from an interview with two Meglen Vlachs, conducted in 2010: Proše Proševski, born in 1936 in Huma, and his son Milan Proševski, born in 1959 in Gudurica ${ }^{15}$.

In March 2014, we went to Gudurica, where, according to our interlocutors, apart from them, only one other villager still spoke the MeglenoRomanian dialect. Our interlocutors were the eldest residents of the village still speaking the language: Kristina and Blagoje Djoševski, born in Huma, in 1925 and 1924, respectively. Their son Pera (b. 1955) also took part in the discussion, but spoke in Serbian only as he understands, but does not speak the dialect. Although Kristina and Blagoje Djoševski spoke Megleno-Romanian (Vlach, as they call their dialect) rarely, they were perfectly fluent in the dialect. Our questions, first asked in Serbian, were answered in Megleno-Romanian as we had asked for at the beginning of the interview. Later, when we started asking questions in Romanian, they both understood them perfectly well, still answering in their dialect. The interview itself took around two hours and was partially directed. Issues of oral history were tackled, as were their life experiences, concentrating on occupations, daily life and traditions ${ }^{16}$.

Recalling their childhood in Huma, Kristina and Blagoje Djoševski, a couple since adolescence, spoke with great satisfaction about Christmas customs, the rough life in the mountains, about the occupations of their parents: agriculture (barley and wheat growing), livestock breading (especially goats and sheep), and production of dairy products, which men would sell in the city. One striking memory of World War II was when the village became located on the front lines. They witnessed fierce fights between partisans, Germans and Bulgarians. Thereafter, the inhabitants were forced to leave, some settling in urban centres, others were "colonized" to other deserted ex-German villages of Yugoslavia. Kristina recalled a moving memory of the alleged death of her then-fiancé, who she believed to have died on the front. After a three-day and three-night journey by the family, and a fruitless search among hundreds of graves, they found out the fiancé was actually alive. The whole village attended a celebration, where the family slaughtered and cooked an ox in the churchyard ${ }^{17}$.

15 S. Nikolin, Meglenoromânii din Banatul de Sud, "Almanah Libertatea" 2012, pp. 130-147.

${ }^{16}$ For details regarding the Megleno-Romanian dialect spoken by our interlocutors in Gudurica, as well as fragments from their conversation, see A. Sorescu-Marinković and M. Măran, Megleno-Romanians in Gudurica.

${ }^{17}$ More on the history and everyday life of our interlocutors in Huma and later in 
We went to Gudurica on a second field trip a few months later just to see on the gate of Djoševski family the funeral announcement about Blagoje's passing away. We still talked to Kristina, who walked us to the grave, showed us photographs and presented us with a solid life philosophy, according to which there is no place for regrets. However, with Blagoje's death, an entire world has died. Field research to Jabuka, the other village where the Meglen Vlachs were colonized, is thus of utmost importance and represents a highly urgent issue, as the community of Meglen Vlach is slowly disappearing.

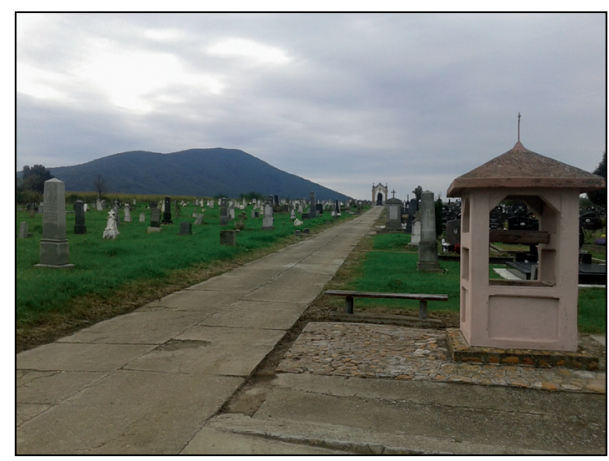

Figure 3. The graveyard in Gudurica, where several Meglen Vlachs are buried, 2014

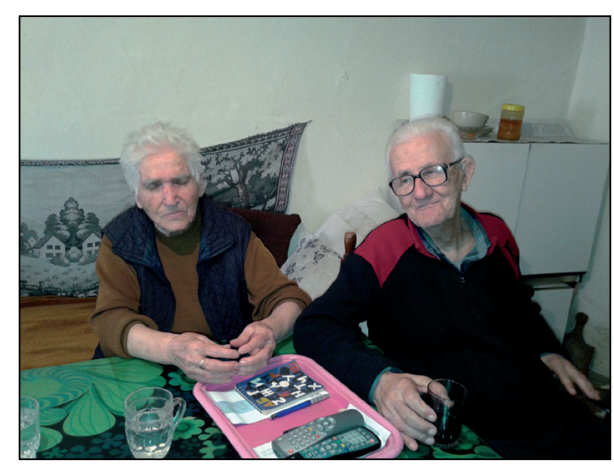

Figure 4. Kristina and Blagoje Djoševski, the terminal speakers of Megleno-Romanian in Gudurica, 2014

\section{SEVERELY ENDANGERED OR ALREADY OBSOLETE LANGUAGE?}

When the Macedonians settled in Vojvodina, the Meglen Vlachs and Aromanians were looked at with bewilderment and ironic comments were made by other villagers because of their strange, unknown language. The minority complex, present even among the officially recognized ethnic minorities, who had schools, media, literature and culture in their mother tongue, was particularly strong among Aromanians and Meglen Vlachs caused fear and shame to speak the language of their ancestors. The use of these dialects was strictly limited to family level and only if the speakers were alone. When persons who did not understand the dialect were present, be they family members or not, these idioms were not used. Today, following the democratization of Serbia, old people in the Serbian Banat,

Gudurica, in: A. Sorescu-Marinković, M. Măran, Megleno-Romanians in Serbia-Shifting Borders, Shifting Identity, in: Contextualizing Changes: Migrations, Shifting Borders and New Identities in Eastern Europe, eds. P. Hristov et al., Sofia 2015, pp. 365-378. 
who still preserve these dialects, have begun to revive their mother tongue and speak it in public.

The descendants of the Aromanians in Serbia, for example, live dispersed for the most part in town settlements and are presently experiencing the revitalization of their heritage language. In Pančevo, a Banat town settlement, Aromanian is currently in the process of being revived by a non-governmental organization (In Medias Res). The language is taught by qualified professors of Aromanian using textbooks from Romania. There is an Association of Aromanians (Lunjina) in Belgrade and among its members are active speakers of Aromanian ${ }^{18}$.

However, Megleno-Romanian is included on the UNESCO list of endangered languages. UNESCO defines four levels of language endangerment, between safe (not endangered) and extinct: vulnerable, definitely endangered, severely endangered and critically endangered. Megleno-Romanian is considered severely endangered, but only taking into account the Meglen Vlach population from the Republic of Macedonia and Greece.

According to the Endangered Languages project, a project by the Alliance for Linguistic Diversity, Megleno-Romanian is a threatened language, spoken by 5,000 native speakers worldwide and there are probably few if any child speakers. A reference is made about the original places where the language was spoken: Greece and the Republic of Macedonia, not of Romania, where the dialect is still spoken with a certain vitality, or Serbia, where the language will probably be extinct in a couple of years.

However, the Megleno-Romanian spoken by our interlocutors, Kristina and Blagoje, was outstandingly preserved, especially considering that after the death of Blagoje's parents they could only speak it to one another. Their son is, nevertheless, only a passive speaker of the dialect. The three family members say they do not understand Aromanians nor the Vlachs of North-Eastern Serbia, but only the Romanians of Serbian Banat, with whom they often come into contact. Despite this, they resort to Serbian when talking to them. Even when the Meglen Vlach community of Gudurica was larger, they would not use their mother tongue in public, for they feared offending other nationalities in the village.

Recalling her childhood and adolescence spent in Huma, Kristina talks about the letters she sent to Blagoje, when he was in the army, which were written both in Serbian and in their Megleno-Romanian dialect, in Cyrillic. The teacher of the village school taught pupils in Serbian only, while the priest, a man from the village, performed the religious service in dialect. Here we should also mention that Thede Kahl, talking about

${ }^{18}$ B. Sikimić, Romanians in Serbian Banat: Dynamic Epistemology, "Slavic Studies" 2014, 61, The Slavic-Eurasian Research Centre Hokkaido University, pp. 51-73. 
the Islamized Meglen Vlachs from Turkey, made the observation that they wrote down their dialect using the Turkish alphabet while those in Greece found their language not suitable for writing at all ${ }^{19}$.

LIVING IN THE SOCIAL FOG OR DISAPPEARING THERE?

Generally, the ethnic identity of the Meglen Vlachs is rather weak, less pronounced than the one of the Aromanians. Their small number and dispersion in several states contributed to this. They do not form a compact community anywhere because of the secular symbiosis with the populations among whom they lived. Assimilation and denationalization policies pursued by their host states, especially after World War I, contributed to this weak identity. Although the language many Meglen Vlachs still speak at home differs from those of surrounding Slavic (Slavic Macedonians, Serbs, Bulgarians) and Greek populations, to most of them this is not enough to give them a sense of belonging ${ }^{20}$. The Meglen Vlachs living in Greece declare themselves Greeks at censuses, those living in Macedonia - Macedonians, and, to a much smaller extent, as Vlachs, and the few who live in Serbia declare themselves as Macedonians.

French anthropologist Dominique Belkis considers that the "historical community" (or "cultural group") of Meglen Vlachs has survived to this day in spite of demographic challenges, processes of assimilation, rural exodus and the general modernization of life style particularly due to an endogenous strategy based on the principle of cultural and social invisibility. More precisely, accepting the exogenous names attributed to the different political context, they comply with the roles imposed upon them by the surrounding society. By not highlighting their cultural differences through identity claims, they protect their endogenous social cohesion ${ }^{21}$. Our interlocutor's statement about changing their family name under different regimes illustrates this: “They were Djošević when the Serbs ruled, then they were Djošev when the Bulgarians came to power, and when the Macedonians took over, they became Djoševski" 22 .

${ }_{19}$ T. Kahl, Čuvanje jezika, gubljenje identiteta: Meglenski Vlasi, in: Skrivene manjine na Balkanu, ed. B. Sikimić, Belgrade 2004, pp. 133-145.

${ }^{20}$ For details about the ethnic identification of the Meglen Vlachs and the process of acculturation, see P. Atanasov, op. cit.; V. Coman, op. cit.; D. Lozovanu, Meglenoromânii - aspecte identitare, geografice, etnoidentitare şi etnodemografice, in: Aromâni, meglenoromâni, istroromâni - Aspecte identitare şi culturale, ed. A. Berciu-Drăghicescu, Bucureşti 2012, pp. 310-343.

${ }^{21}$ D. Belkis, Vers une définition de la "méglénité", "Martor. The Museum of the Romanian Peasant Anthropology Review" 2001, 6, pp. 205-237.

${ }^{22}$ Fragment of the interview with Pera Djoševski (Gudurica 2014). 
The mother tongue of our interlocutors is Megleno-Romanian, at school in Huma they were taught exclusively in Serbian, they do not know Macedonian, but can easily understand it because of the similarities between these two Slavic languages, and at population censuses they declare themselves as Macedonians. At state level, this makes them virtually invisible as an ethnic community. Dominique Belkis, in an interview with Romanian anthropologist Vintilă Mihăilescu, spoke about the "negative identity constructions" of the Meglen Vlachs, adding that "this does not mean that the absence of claims on behalf of ethnic identity signifies a lack of reference and identity consciousness or a difficulty in instrumentalizing the collective identity" ${ }^{23}$. We think another theoretical construct might be of help here: living in the social fog ${ }^{24}$. Namely, the Meglen Vlachs wish to level up, to adjust and to adapt and to become invisible, living in the comfortable social fog, as a strategy of survival.

\section{CONCLUSIONS}

The linguistic and cultural future of the Meglen Vlachs inevitably leads to acculturation and assimilation. Romanian ethnologist Emil Țîrcomnicu thinks the Megleno-Romanian dialect will be extinct in 50 years at a maximum due to the small number of speakers and dispersion over a vast territory over several states ${ }^{25}$. In Serbia, as we mentioned, the dialect might already be obsolete. Linguist Petar Atanasov, however, considers that education in standard Romanian could help preserve the dialect by re-awakening the national conscience of the speakers. Obviously, cultural policies of the Romanian state could raise the interest in the preservation and use of Megleno-Romanian. In Vojvodina, with a large Romanian minority, the Meglen Vlach descendants could use the already existing schooling in Romanian in order to revive their ethnic identity and their ancestral language. While we can only hope that the nightmare of every researcher will not come true in our case: the community freshly discovered was discovered too late to do anything in order to help it survive...

${ }^{23}$ V. Mihăilescu, Lecția megleno-română. Interviu cu Dominique Belkis, in: Balcani după Balcani, Bucureşti 2000, pp. 23-32.

${ }^{24}$ D. S. Massey et al., Theories of International Migration: a Review and Appraisal, "Population and Development Review" 19, 1993, 3, pp. 431-466.

${ }^{25}$ J. F. Țîrcomnicu, Meglenoromânii - destin istoric şi cultural, București 2004. 


\section{BIBLIOGRAPHY}

Atanasov P., Meglenoromâna astăzi, Bucureşti 2002.

Belkis D., Vers une définition de la "méglénité", "Martor. The Museum of the Romanian Peasant Anthropology Review" 2001, 6.

Coman V., Scurtă privire asupra meglenoromânilor până la sfârşitul secolului al XX-lea, in: Aromâni, meglenoromâni, istroromâni - Aspecte identitare şi culturale, ed. A. Berciu-Drăghicescu, Bucureşti 2012.

Jireček K., Über die Wlachen von Moglena, "Archiv für Slavische Philologie" 1893, 15.

Kahl T., Čuvanje jezika, gubljenje identiteta: Meglenski Vlasi, in: Skrivene manjine na Balkanu, ed. B. Sikimić, Belgrade 2004.

Kahl T., The Islamisation of the Meglen Vlachs (Megleno-Romanians): The Village of Nânti (Nótia) and the "Nântinets", "Nationalities Papers" 2006, 34, 1.

Lozovanu D., Meglenoromânii - aspecte identitare, geografice, etnoidentitare şi etnodemografice, in: Aromâni, meglenoromâni, istroromâni - Aspecte identitare şi culturale, ed. A. Berciu-Drăghicescu, Bucureşti 2012.

Massey D. S. et al., Theories of International Migration: a Review and Appraisal, "Population and Development Review" 1993, 19, 3.

Mihăilescu V., Lecția megleno-română. Interviu cu Dominique Belkis, in: Balcani după Balcani, Bucureşti 2000.

Mladenovski S., Банатско село Јабука, Скопје 1988.

Nikolin S., Meglenoromânii din Banatul de Sud, "Almanah Libertatea" 2012.

Pleterski J. et al., Istorija Saveza komunista Jugoslavije, Beograd 1985.

Saramandu N., Die Aromunen in der Dobrudsha und ihre Mundart, "Dacoromania" 1975, 3.

Sikimić B., Romanians in Serbian Banat: Dynamic Epistemology, "Slavic Studies" 2014, 61, The Slavic-Eurasian Research Centre Hokkaido University.

Sorescu-Marinković A., Măran M., Megleno-Romanians in Gudurica: Language and Identity, "Memoria Ethnologica" 2014, 52-53.

Sorescu-Marinković A., Măran M., Megleno-Romanians in Serbia - Shifting Borders, Shifting Identity, in: Contextualizing Changes: Migrations, Shifting Borders and New Identities in Eastern Europe, eds. P. Hristov et al., Sofia 2015.

Ţî̀rcomnicu E., Meglenoromânii - destin istoric şi cultural, Bucureşti 2004.

Trifunoski J. F., O posleratnom naseljavanju stanovništva iz NR Makedonije u tri banatska naselja - Jabuka, Kačarevo i Glogonj, Novi Sad 1958.

Weigand G., Vlacho-Meglen. Eine ethnographisch-philologische Untersuchung, Leipzig 1892.

\section{ABSTRACT}

The paper aims at presenting the Meglen Vlach community of Serbia, situated in a few villages near the border with Romania. Because of the very small number of members, this community has so far not been known to the scientific community or to the majority population of Serbia. The Meglen Vlachs arrived there in the 1950s from Huma (today in the FY Republic of Macedonia) and were "invisible" in official statistics as they were "concealed" among the Macedonian colonists, intended to repopulate, together with other Yugoslavs, the former German villages. However, many of them left shortly after, to return home, settle in other Macedonian localities or to migrate to Western European countries. Today, the Meglen Vlach dialect is actively spoken in Serbia by only a few people (terminal speak- 
ers, in linguistic terms), born in the inter-war period. The paper tries to determine whether their idiom is severely endangered (like the Meglen Vlach dialect in the other countries where it is spoken) or has already become an obsolete language. Finally, the article shows that the linguistic and cultural future of the Meglen Vlachs in Serbia inevitably leads to acculturation and assimilation.

Key words: Meglen Vlachs, invisible minority, Yugoslavia, endangered language

\section{ABOUT AUTHORS}

Annemarie Sorescu-Marinković - a research fellow at the Institute for Balkan Studies in Belgrade (Serbia). She received her BA and MA at the Philology Faculty of the West University of Timişoara (Romania), and her PhD at the "Babeş-Bolyai" University of Cluj-Napoca (Romania), with a thesis on Vlachs of Eastern Serbia. Her areas of interest are the folklore, language and identity of Romanian-speaking communities in the Balkans. She is the author of the monograph Românii din Timoc astăzi. Ființe mitologice (The Vlachs of Eastern Serbia Today. Mythological Beings), 2012, the co-author of the album Românii de lângă noi (The Romanians Near Us), 2013, and has published more than 50 academic papers in international peer-reviewed journals.

Mircea Măran - a professor at the Pre-school Teacher Training College "Mihailo Palov in Vršac. He graduated from the Philosophy Faculty of the University of Novi Sad, where he also got his MA and PhD, with a thesis on the cultural situation of Romanians in the Serbian Banat between 1945 and 1952. His research interests are the history of Romanians in the Serbian Banat, and Romanian-Serbian relations. He is the author of several monographs, among which are Românii din Voivodina (The Romanians in Vojvodina), 2011, Românii din Banatul sârbesc în anii interbelici 1918-1941 (The Romanians in the Serbian Banat in the Interwar Years 1918-1941), 2012, and has published more than 50 academic papers in international peer-reviewed journals. 